\title{
DEBUTS
}

Aleksandra Guss*

aleksandra.guss@phdstud.ug.edu.pl

orcid.org/0000-0002-4157-6853

University of Gdańsk

Faculty of Law and Administration

Jana Bażyńskiego 6

80-980 Gdańsk, Poland

\section{The Digitization of Cultural Heritage under Polish Law and Policy: Challenges Presented by Copyright Law}

\begin{abstract}
Digitization in the narrow sense means the conversion of analogue data into digital form. Looking more broadly through the prism of the protection of cultural heritage, digitization of its objects means not only the conversion of analogue objects into their digital version, but is also related to the processing of the obtained material, file management, and finally, but not always, the sharing of digital documentation. It is not a simple procedure because it has many limitations, including those arising from issues of the copyright protection of digitized works. The aim of this article is to present the challenges related to copyright in relation to the digitization of cultural heritage in the light of Polish law and policy. Poland is one of the countries where the process of digitization of cultural heritage is developing dynamically, both through government programmes and grassroots digitization movements. However, there is no separate regulation in the Polish legal system devoted to the digitization of cultural heritage resources. This makes it difficult to ensure the digitization of a significant part of collections due to the limitations resulting from copyright and their relation to works that can potentially be transferred into the digital space.
\end{abstract}

\footnotetext{
* Aleksandra Guss is a graduate of law at the Faculty of Law and Administration of the University of Gdańsk (Poland), PhD Candidate in law at the University of Gdańsk. Her research interests include the aesthetics of law, the legal protection of cultural heritage, and intellectual property law.
} 


\section{DEBUTS}

Aleksandra Guss

Keywords: digitization, cultural heritage, copyrights, digital heritage

\section{Introduction}

The digitization process has now indeed become an important element of the mandate of various public cultural institutions, as well as of the activities of private individuals and informal groups across the world. The importance of digitizing cultural heritage was noted by UNESCO in its Charter on the Preservation of Digital Heritage, ${ }^{1}$ which stressed that cultural resources have special value and are significant for the society and for people's cultural identity and therefore deserve to be provided the adequate protection that digitization offers. With the help of digitization, cultural heritage can be saved from destruction or oblivion.

Thanks to the development of modern technologies, it has become easier to protect cultural goods by creating their digital representations, which can easily be shared with millions of users around the world via the Internet. Due to the fact that cultural and memory institutions are responsible for collecting, storing, and sharing cultural heritage, they have to meet the challenges connected with its digitization. One of the barriers that complicates the process of sharing cultural heritage on-line are the restrictions resulting from legal constraints.

Unsurprisingly, making digitized content available via the Internet is closely related to intellectual property law solutions, and in particular copyright, which is a significant part of intellectual property law. Undoubtedly, copyright provisions and regulations exert a strong influence on the practice of digitizing cultural collections, often extending its process.

In this context, the stage before the digitization process is important, as the legal status of objects needs to be sorted out during this phase, including the issues of using their digital reproductions and metadata. In addition the digitization of a given subject depends on where the digitization occurs. In the European context, this issue was the subject of the Commission Recommendation of 27 October 2011 on the digitization and online accessibility of cultural material and digital preservation. ${ }^{2}$ This Recommendation can be viewed as a follow-up of the launch in 2008 of Europeana, which is comprised of a multilingual digital library, archive, and museums containing the cultural heritage of Europe. ${ }^{3}$ The Commission noted

115 October 2003, http://portal.unesco.org/en/ev.php-URL_ID=17721\&URL_DO=DO_TOPIC\&URL_ SECTION=201.html [accessed: 18.06 .2020 ].

2 OJ L 283, 29.10.2011, p. 39.

3 T. Wasiołka, Ochrona dziedzictwa kulturowego na tle standardów europejskich [Protection of Cultural Heritage Compared to European Standards], unpublished MA thesis, University of Zielona Góra, Zielona Góra 
in point 11 of the 2011 Recommendation that not all the library, archival, and museum resources were in the public domain, i.e. they had not all ceased to be the subject of intellectual property rights, including in particular copyright. The Commission also emphasized that since intellectual property rights are a key tool for promoting creativity, Europe's cultural heritage should be digitized and shared in a form that fully protects and respects copyright and related rights.

The purpose of this article is to examine the challenges copyright law poses in the process of digitizing cultural heritage under Polish law and policy. While scrutinizing the legal framework in force, combining the perspective of the law of the European Union (EU) of which Poland is a Member State, the practice of public programmes on digitization of cultural heritage resources is analysed. Poland is one of those countries where the process of digitization of cultural heritage is developing dynamically, both through government programmes and grassroots digitization movements. Yet there is no separate regulation in the Polish legal system devoted to the digitization of cultural heritage resources. This makes it difficult to ensure the digitization of a large part of collections due to the limitations resulting from copyright law and their relation to cultural manifestations that can potentially be transferred to the digital space. This article concludes by identifying avenues to overcome the recurring tensions between safeguarding cultural heritage and providing access to it, while at the same time protecting competing rights under intellectual property law.

\section{Cultural Heritage and Its Digitization}

The term "digitization" still causes many interpretation problems, because it does not have a single, uniform, and clear definition. In the narrow sense digitization refers to the conversion of analogue data into digital form. ${ }^{4}$ This is a very general definition and applies to all items that can be transferred to the digital space. In this article, the meaning of the term "digitization" is examined with respect to cultural heritage. As defined in UNESCO's Fundamental Principles of Digitization of Documentary Heritage, digitization is the creation of digital culture objects from physical, analogue originals by means of a scanner, camera, or other electronic device. ${ }^{5}$ It is undertaken as part of a process that includes the selection, assessment, prioritization, and preparation of originals for digitization, metadata collection and

2017, p. 51; also see B. Valtysson, Europeana. The Digital Construction of Europe's Collective Memory,"Information, Communication \& Society Journal" 2012, Vol. 15(2), pp. 151-170; J. Purday, Europeana: Digital Access to Europe's Cultural Heritage, "Alexandria: The Journal of National and International Library and Information Issues" 2012, Vol. 23(2), pp. 1-13.

4 See J.S. Brennen, D. Kreiss, Digitization, in: K. Jensen et al. (eds.), The International Encyclopedia of Communication Theory and Philosophy, Wiley-Blackwell, Chichester 2016, pp. 556-566.

5 UNESCO, Fundamental Principles of Digitization of Documentary Heritage, http://www.unesco.org/new/ fileadmin/MULTIMEDIA/HQ/CI/Cl/pdf/mow/digitization_guidelines_for_web.pdf [accessed: 14.08.2020]. 


\section{DEBUTS}

Aleksandra Guss

creation etc. Access to digital information should be guaranteed for everyone as a human right. Digital infrastructure and technology should consider digital divide and sustainable accessibility. ${ }^{6}$ For instance, according to the guidelines issued by the United States National Archives and Records Administration (NARA), ${ }^{7}$ digitization covers a number of activities, the end result of which is a digital copy, made available to users via the Internet or other channels over a long period of time. These activities include identification and selection of documents, their organization and maintenance, collection of basic metadata, digital conversion, and enabling the user to access the digitized documents in electronic form.

In the Polish legal order there is no legal definition of digitization, but for the purposes of governmental cultural programmes a general definition of this process has been created. According to the definition used in the Polish Digital Culture Programme ${ }^{8}$ digitization is the processing of analogue materials into digital form by scanning or photographing, and further computer processing of the obtained images into a form that allows them to be shared (e.g. on the Web). This term is most often used to refer to activities carried out by libraries, museums, or archives, i.e. institutions that collect, store, and make available to recipients various materials. These institutions digitize their collections by creating digital images of them, which they then convert and make available to users. Sharing takes place through the publication of digitized material on the Internet, e.g. in a digital library, archive, digital repository, or on an institution's website. Due to copyright restrictions, some materials may not be made available on the Internet and may only be used on the premises of the institution that stores them. On the basis of this definition, we can observe that while digitization does not always make a given object available to a wide group of recipients, nevertheless such action is extremely desirable and should be, in addition to the protection of given cultural heritage objects, the goal of digitization.

For the purposes of this article, it will be assumed that the most basic goal of digitization in the narrow sense of the term is to obtain a digital representation of objects, i.e. to perform a digital representation with a digital camera or scanner, and to equip this data with appropriate descriptive metadata. The next steps, concerning digitization in the broader sense, relate to the processing of the obtained material, file management, and finally the sharing of digital documentation, in the spirit of cultural heritage as broadly understood, in its tangible and intangible dimensions. ${ }^{9}$

\footnotetext{
6 Ibidem.

7 The U.S. National Archives and Records Administration, Strategy for Digitizing Archival Materials, https:// www.archives.gov/digitization/strategy.html [accessed: 14.08.2020].

8 Ministerstwo Kultury i Dziedzictwa Narodowego, O digitalizacji [On Digitization], http://kulturacyfrowa. mkidn.gov.pl/pages/digitalizacja/o-digitalizacji.php [accessed: 14.08.2020].

9 See R. McCain, Defining Cultural and Artistic Goods, in: V.A. Ginsburg, D. Throsby (eds.), Handbook of the Economics of Art and Culture, Vol. I, North-Holland, Amsterdam 2006, p. 147.
} 
The above definition (in the broader sense) is essentially built on the provisions of UNESCO's 2003 Charter, which in Article 1 defines digital heritage as unique resources of human knowledge and expression. It embraces cultural, educational, scientific, and administrative resources, as well as technical, legal, medical, and other kinds of information created digitally, or converted into digital form from existing analogue resources. In cases where resources are "born digital", there is no other format but the digital object. Digital materials include texts, databases, photographs and film and audio materials, graphics, software, and websites in a wide range of formats. The main purpose of the Charter is to point out that digital heritage is also vulnerable to loss due to the aging of the devices and software by which the heritage was created. Therefore, appropriate legal and institutional solutions should be ensured, including in particular the inclusion of digital heritage in the deposits of libraries, archives, and other public repositories, and the design of systems that will create authentic and stable digital objects.

As the Charter emphasized, the owners of copyright and related rights should be included in the process of creating standards and creating the appropriate cultural policy. It is only then that the legal framework for digitizing specific objects can be outlined. This is however a challenge, both for the European and Polish legal spaces.

\section{The Process of Creating Digital Cultural Heritage in the EU and the Issue of Copyright}

Before I refer to the Polish case, it is impossible not to refer to European regulations on digitization and the problems of copyright connected with them, because it is the actions of the EU that have become the basis for digital programmes in Poland.

Under the Treaty on the Functioning of the European Union, ${ }^{10}$ in the context of cultural policy the EU only has a supporting and complementary role, while direct responsibility in this area lies with the individual Member States (Article 167). For this reason the actions of the EU in the field of digital culture are founded on a matrix of supporting and legislative measures stemming from the Union's distinct competences to address issues of the Single Market (including the digital market), copyright, ${ }^{11}$ and culture.

One of the first activities undertaken by the EU to digitize cultural heritage was to implement the vision of a European digital library. The Council Resolution

\footnotetext{
10 Consolidated version: OJ C 202, 7.06.2016, p. 47.

11 For more discussion in this regard, see A. Ramalho, The Competence of the European Union in Copyright Lawmaking. A Normative Perspective of EU Powers for Copyright Harmonization, Springer Publishing, Cham 2016.
} 


\section{DEBUTS}

Aleksandra Guss

of 25 June 2002 on preserving tomorrow's memory - preserving digital content for future generations ${ }^{12}$ emphasized the role of digitization in preserving the cultural heritage of the future and drew attention to the need to change the methods of creating, storing, and preserving recordings, documents, and the content of archives, in particular due to technological progress. The Commission Recommendation of 24 August 2006 on the digitization and online accessibility of cultural material and digital preservation ${ }^{13}$ also had a significant impact on the creation of the first online collections. ${ }^{14}$

The European Digital Library (Europeana) was established in 2008 as the implementation of the i2010 Communication: Digital Libraries, presented by the Commission in 2005. Europeana's priority is to enable and promote access to the rich cultural resources of libraries, archives, and museums from all over Europe. At the time of its opening, Europeana offered access to around 4.5 million objects, and currently includes almost 50 million books, magazines, maps, photographs, and documents in digital form, coming from the cultural institutions of European countries. ${ }^{15}$ The 2006 Recommendation also pointed out activities and their development in the field of planning and monitoring the digitization of cultural heritage, as well as improving the conditions for the digitization and availability of copyright-protected materials on the Internet by creating the framework legal conditions enabling the conclusion of license agreements. The Creative Commons Zero Universal Domain Dedication (CCO) license, which is mainly used by Europea$n a$, is based on the unilateral statement of the creator, who/which waives all rights that can be waived in a given legal system, and then, ideally, such a work goes into the public domain. Such a work can be multiplied, changed, and disseminated. ${ }^{16}$ This mechanism has been developed to enable the sharing of copyrighted works on an equal footing with works in the public domain - its use means a waiver of rights to a given work as far as possible in a given legal system. ${ }^{17}$ However, few authors decide on such solutions - mainly for economic reasons - thus closing off access of the majority of society to their works.

12 OJ C 162, 6.07.2002, p. 4.

13 OJ L 236, 31.08.2006, p. 28.

14 A. Bożek, L. Kamińska-Mazur, Europeana - cyfrowa kolekcja europejskiego dziedzictwa kultury [Europeana - A Digital Collection of European Cultural Heritage], "Folia Bibliologica" 2009, Vol. 51, p. 130.

15 Information from the official website of the European Digital Library, https://www.europeana.eu [accessed: 18.04 .2020$]$.

16 CC0 1.0 Universal - Public Domain Dedication, https://guides.lib.umich.edu/creativecommons/licenses [accessed: 18.04.2020].

17 See E. Manikowska, Digitization: Towards a European Cultural Heritage, in: A. Jakubowski, K. Hausler, F. Fiorentini (eds.), Cultural Heritage in the European Union: A Critical Inquiry into Law and Policy, Brill, Boston-Leiden 2019, pp. 417-444; E. Stainforth, From Museum to Memory Institution: The Politics of European Culture Online, "Museum \& Society" 2016, Vol. 14(2), pp. 323-337. 
Another important act concerning the digitization of cultural heritage is Directive 2012/28/EU of the European Parliament and of the Council of 25 October 2012 on certain permitted uses of orphan works. ${ }^{18}$ Before this Directive, the issue of orphan works created a major obstacle to the mass-scale digitization of copyrighted works, and there was a desperate need for international harmonization of the law. ${ }^{19}$ In accordance with Article 2(1) of Directive2012/28/EU, a work or a phonogram shall be considered an orphan work if none of the rights holders in that work or phonogram are identified, or even if one or more of them can be identified but cannot be located, provided a diligent search ${ }^{20}$ for the rights holders has been carried out and recorded. The Directive states that publicly accessible museums, libraries, archives, and other institutions should keep a record of their diligent searches ${ }^{21}$ and of works that are still copyrighted but the identity or location of the copyright owners cannot be determined. If the search result is negative and the author's identity or location has not been established, the orphan work may be used legitimately, as Article 6 of the Directive allows its public disclosure by the aforementioned organizations, as well as carrying out acts of reproduction of an orphan work for the purposes of digitization, sharing, indexing, cataloguing, protection, and renewal. ${ }^{22}$

Importantly, one of the core objectives of the EU copyright legislation is to ensure the level of protection required to foster creativity and investment in creativity, and to promote cultural diversity, while at the same time providing better access for consumers and businesses to digital content and services across Europe. In this respect, Directive 2001/29/EC of the European Parliament and of the Council of 22 May 2001 on the harmonisation of certain aspects of copyright and related rights in the information society ${ }^{23}$ laid the foundation for the creation of a harmonized legal framework on copyright and related rights, thereby improving legal certainty while ensuring a high level of intellectual property protection. Yet, when referring to the digitization of cultural heritage, perhaps

\footnotetext{
18 OJ L 299, 27.10.2012, p. 5.

19 K. de la Durantaye, Finding a Home for Orphans: Google Book Search and Orphan Works Law in the United States and Europe, "Fordham Intellectual Property, Media \& Entertainment Law Journal" 2010, Vol. 21(2), pp. 229-230.

20 The term "diligent search" as used means the process of checking information by cultural institutions (libraries, museums, archives), based on sources appropriate for particular categories of works and other protected objects, before using the work or a phonogram.

21 D. Pietruch-Reizes, Digitalizacja i rozpowszechnianie utworów osieroconych w świetle dyrektywy Parlamentu Europejskiegoi Rady 2012/28/UE z 25 października 2012 r. [Digitization and the Distribution of Orphan Works under Directive 2012/28/EU of the European Parliament and of the Council of 25 October 2012], "Przegląd Biblioteczny" 2014, Vol. 4, p. 557; see also U. Suthersanen, Property and Culture: A Case Study on Orphan Works, "Art Antiquity and Law" 2017, Vol. 22(2), pp. 172-191.

22 D. Pietruch-Reizes, op. cit., p. 558.

23 OJ L 167, 22.06.2001, p. 10.
} 


\section{DEBUTS}

Aleksandra Guss

the most significant directive is Directive (EU) 2019/790 of the European Parliament and of the Council of 17 April 2019 on copyright and related rights in the Digital Single Market and amending Directives 96/9/EC and 2001/29/EC, adopted and entered into force on 7 June 2019.24 In fact, this Directive gave rise to a number of controversies, as it was the first time that the EU decided to introduce a mandatory implementation of restrictions on exclusive rights. Indeed, this Directive introduces the obligation to implement three exceptions to copyright protection: the first concerns the use of texts and data for the purposes of scientific research; the second for didactic activities; and the third for the needs of preservation of collections by cultural heritage institutions. The third exception is particularly relevant to this article. Such an exception should be interpreted broadly: in accordance with recitals 27 and 28 of the Directive it is intended to allow archiving (irrespective of the medium or format of the work) in an appropriate amount (which cannot be quantified in national law) at any time (the decision should therefore be left to cultural heritage institutions) and to the extent necessary to preserve such collections. The requirement is to have the works and other items of copyright permanently listed in the commented provisions in the institution's collections (thus all items of copyrighted materials available on the basis of an inter-institutional loan will fall outside the scope of application of this Directive).

The protection of intellectual property rights is an important issue in the organization of these resources. European cultural heritage should be digitized, shared, and protected while respecting copyright and related (intellectual property) rights. Under current EU legislation, digitized resources can only be made available to the public if they are copyright-free or if the author has consented to them being made available. Therefore, at the beginning Europeana accumulated copyright-free resources, becoming a propagator of the public domain, which includes two types of works: works for which copyrights have expired (however, in some European countries they may still be subject to lifetime personal copyrights) and items that are not protected by copyright, i.e. legal acts, judgments, and administrative rulings as well as short press information. According to Europeana's Public Domain Charter, ${ }^{25}$ the term of protection under copyrights is limited in time and should not be extended - this allows more objects to enter the public domain that, due to their intrinsic value, contribute to the development of society. Moreover, elements that are already in the public domain should remain therein and it is not possible to re-establish exclusive rights to a work that is in the public domain; and as well access to reproduction of any such digital work cannot be restricted by any means, technical or contractual. ${ }^{26}$ If any work has entered into the public

24 OJ L 130, 17.05.2019, p. 92.

25 Europeana, Public Domain Charter, https://www.europeana.eu/pl/rights/public-domain-charter [accessed: 17.04 .2020$]$. 
domain in an analogue version, then any digital version later created will also be in the public domain. The legal status of a work in the public domain guarantees that the work can be used, copied, and modified, which means that access to it is very wide and its use can be equally extensive, i.e. developing new theories, inventions, and cultural works.

\section{Cultural Heritage under Polish Law and Policy}

The digitization of the collections of European museums, libraries, and archives provides a means to preserve cultural heritage, and at the same time also democratizes it and thus increases European integration. ${ }^{27}$ It is highly desirable to harmonize the laws of the Member States on the digitization of cultural heritage as much as possible, and to create a digital single market, while at the same time respecting copyright protections. Poland is one of those countries which has successfully implemented European regulations regarding both digitization and copyrights to its legal order, albeit not without a number of challenges.

Today in the Polish legal system there is still no general and coherent legal act adopted with the purpose of establishing unified rules for the acquisition or disposal of cultural goods by public entities. ${ }^{28}$ The need to ensure adequate protection of cultural heritage is already treated in the Constitution of the Republic of Poland, ${ }^{29}$ which in its Article 5 indicates that the Republic of Poland is guardian of the national heritage, and in Article 6(1) indicates that the Republic of Poland creates conditions for the dissemination and equal access to cultural goods which are a source of the identity of the Polish nation, its duration, and development. These provisions have systemic implications in the sense that their normative meaning extends to the entire legal system, and the direct addressee of the obligations expressed in them is the State in its entirety, and consequently all its organs although these tasks are carried out by a specialized government administrative body subordinated to the central authority: the Ministry of Culture and National Heritage $(\mathrm{MCNH}) .{ }^{30}$ The importance of these provisions also results from the Polish legal principle mandating the systemic interpretation rule a rubica - the location of national heritage issues at the beginning of the Basic Law demonstrates that the Polish constitutional framework grants it a special rank, recognizing them as one of

27 A. Jakubowski, K. Hausler, F. Fiorentini, Final Conclusions, in: A. Jakubowski, K. Hausler, F. Fiorentini (eds.), Cultural Heritage in the European Union: A Critical Inquiry into Law and Policy, Brill, Boston-Leiden 2019, p. 455.

28 M. Drela, Culture Goods in the Public Domain under Polish Law - Acquiring and Disposing Difficulties, "Santander Art and Culture Law Review" 2015, Vol. 2, p. 1.

29 Konstytucja Rzeczypospolitej Polskiej z dnia 2 kwietnia 1997 r., Dz.U. 1997 No. 78 item 483.

30 K. Zeidler, Zasady prawa ochrony dziedzictwa kultury - propozycja katalogu [The Principles of the Law on the Protection of Cultural Heritage - A Proposal for a Catalogue], "Ruch Prawniczy, Ekonomiczny i Socjologiczny" 2018, Vol. 4, p. 150. 


\section{DEBUTS}

Aleksandra Guss

six values that deserve special protection, ${ }^{31}$ which protection measures are introduced via the executive acts of the $\mathrm{MCNH}$.

The policy of protecting cultural heritage is part of the national cultural policy of the State, implemented by public authorities and non-governmental organizations. These are primarily long-term activities designed to meet the needs and solve problems in the field of cultural heritage. Unlike the cultural heritage protection system, the cultural heritage protection policy includes activities planned and implemented in accordance with the prescribed procedures, while the protection system functions as a result of the implemented policy, but also is the result of the actions of various entities other than state and local government authorities, not all of whose actions and consequences have been planned or provided for. It can therefore be said that the cultural heritage protection system has a broader scope, involving both legal and policy goals and instruments.

Accordingly, Polish cultural heritage policy is primarily designed, revised, and developed within the "National programme for the protection of monuments and care for monuments", enacted by the Council of Ministers, first for the years 2014-2017, and currently for the period 2019-2022. ${ }^{32}$ The programme for 2014-2017 primarily assumed the strengthening of the role of cultural heritage and the protection of monuments in the development of the cultural and creative potential of Polish citizens, which was to be implemented by supporting systemic solutions for the protection of monuments in Poland, strengthening the synergy of protection bodies, and creating conditions for active participation in culture, education about cultural heritage, and its promotion. ${ }^{33}$ The objectives of the 2019-2022 programme are to create conditions for the effective protection and care of monuments, which consists of optimization of the cultural heritage protection system, providing support for the care of monuments, and building public awareness of the value of cultural heritage. ${ }^{34}$

31 K. Zeidler, Prawo ochrony dziedzictwa kultury [Law on the Protection of Cultural Heritage], Wolters Kluwer, Warszawa 2007, p. 44.

32 Council of Europe, Cultural Heritage Policy in Poland - National Policy Report, https://www.coe.int/en/ web/herein-system/poland [accessed: 21.06.2020].

33 Uchwała nr 125/2014 Rady Ministrów z dnia 24 czerwca 2014 r. w sprawie „Krajowego program ochrony zabytków i opieki nad zabytkami" [Resolution No. 125 of the Council of Ministers of 24 June 2014 regarding the "National Programme for the Protection of Monuments and Care for Monuments"], http://bip.mkidn. gov.pl/media/download_gallery/20140818Krajowy_Program_Ochrony_Zabytkow_i_Opieki_nad_Zaby. pdf [accessed: 21.06 .2020 ]. Total financing of the programme from the state budget and beneficiaries' own resources amounted to PLN 26,688,200.

34 Uchwała nr 82 Rady Ministrów z dnia 13 sierpnia 2019 r. w sprawie „Krajowego program ochrony zabytków i opieki nad zabytkami na lata 2019-2022" [Resolution No. 82 of the Council of Ministers of 13 August 2019 regarding the "National Programme for the Protection of Monuments and Care for Monuments for the Years 2019-2022"], http://isap.sejm.gov.pl/isap.nsf/download.xsp/WMP20190000808/O/M20190808. pdf [accessed: 21.06.2020]. The objectives are achieved by means of, inter alia, trainings for local government units in the field of cultural heritage management; building knowledge about the protection of cultural heritage at the local, regional, and central levels; supporting the development of competences 


\section{Digitization of Cultural Heritage in Poland: The Practice}

The first steps in the digitization of cultural heritage in Poland were taken by libraries, archives, museums, non-governmental organizations, and other entities, which gave birth to a social movement for the digitization of culture, i.e. the socalled "grassroots digitization", which today through its informal activities acts as a kind of complement to institutionalized projects. ${ }^{35}$ One of the first projects implemented under the grassroots digitization concept was the Social Digitization Workshop, ${ }^{36}$ launched by the Silesian Library in Katowice in 2007, which creates the digital resources of the Silesian Digital Library. This workshop was a direct support for this library, as part of it was aimed at creating hardware and software facilities - the studio - enabling the faster scanning and processing of digital materials, as well as training and consulting activities provided to the Library units and employees. The studio has become a centre of media education, directing its activities to a wider audience, offering student internships, library lessons, training sessions, and workshops for students and schoolchildren. ${ }^{37}$ Proof of the uniqueness of this undertaking is its enabling volunteers and seniors to work on scanning publications. Another aspect of the studio's activities is its opening up of objects from private collections, which otherwise would not be able to reach a wide audience. In 2009, another Social Digitization Workshop was opened at the Baltic Digital Library in Słupsk. ${ }^{38}$ Both workshops benefited from funding from the MCNH programme "Mecenat". What is important is that both institutions have shown that you can carry out the digitization process, considered to be expensive, by investing only in equipment and training, and the educational dimension of their activities indicates that digitization work can also be entrusted to amateurs coming from outside librarians or museologists' circles.

Within the framework of implementing EU standards, the 2010 Ordinance of the Minister of Culture and National Heritage recommended the preservation of materials of historical value by creating copies, records, and archives, and appointed a team for digitization. ${ }^{39}$ The same year, the Digital National Library

by employees in conservation services; and conducting social and educational campaigns in the media. The programme is financed from the state budget and PLN 25,617,089 was allocated to it.

35 A. Tarkowski, J. Hofmokl, M. Wilkowski, Digitalizacja oddolna. Partycypacyjny wymiar procesu digitalizacji dziedzictwa [Bottom-up Digitization. The Participatory Dimension of Heritage Digitization], p. 3, http:// www.nina.gov.pl/media/43941/digitalizacja-oddolna.pdf [accessed: 21.06.2020].

36 Śląska Biblioteka Cyfrowa, Społeczna Pracownia Digitalizacji ŚBC [Social Digitization Workshop of the SDL], https://www.sbc.org.pl/dlibra/text?id=spd\&amp;language=pl [accessed: 21.06.2020].

37 A. Koszowska, R. Lis, Społeczna Pracownia Digitalizacji ŚBC [Social Digitization Workshop of the SDL], "Biblioteka 2.0", 30 September 2007, http://blog.biblioteka20.pl/?p=49 [accessed: 21.06.2020].

38 https://www.bibliotekacyfrowa.eu/dlibra?language=en [accessed: 21.06 .2020$]$.

39 Zarządzenie nr 23 Ministra Kultury i Dziedzictwa Narodowego z dnia 16 września 2010 r. w sprawie powołania Zespołu do spraw polityki audiowizualnej I cyfryzacji w dziedzinie kultury w Ministerstwie Kultury i Dziedzictwa Narodowego [Ordinance No. 23 of the Minister of Culture and National Heritage of 16 Sep- 


\section{DEBUTS}

Aleksandra Guss

Polona was launched, based on the resources of the National Library. ${ }^{40}$ It allows access to its resources through collections and catalogue searches, having various types of library documents: books, magazines, graphics, photography, drawings, and social life documents. Nevertheless, the digital documents that make up Polona did not initially meet international quality standards for digital objects due to the low resolution of the digital files and the lack or incompleteness of metadata. Hence since 2008 work has been undertaken to adapt Polona's resources to European standards. In this regard, the Szukaj w Archiwach project was launched by the National Digital Archive ${ }^{41}$ in 2009. The main goal of the project was to create an internet portal wherein scans and descriptions of archival materials in the holdings of Polish archives are presented.

However, in the area of digitization activities a complex multi-pronged problem was noted: namely that the activities were conducted by many libraries, museums, and audio-visual centres and that the process was characterized by a lack of coordination of activities; a lack of an adequate system of financing digitization work at the central level; and a low level of knowledge regarding the importance of the process of digitization of Polish cultural goods among managers of institutions. Therefore the $\mathrm{MCNH}$ has implemented a programme aimed at presenting guidelines for digitization of national heritage. The Programme of Digitization of Cultural Goods and the Collection, Storage, and Sharing of Digital Objects in Poland $2009-2020^{42}$ is the first project financed by governmental funds aimed at transferring Polish cultural goods to the Internet space. The programme encompasses issues such as the missions and goals of the digitization of cultural heritage, as well as legislative, institutional, and financial instruments for programme's implementation. In addition, three main activities have been identified, the implementation of which will be key: the expansion of Polish digital resources; the protection of the digital resources; and ensuring access to the digital resources. ${ }^{43}$

tember 2010 regarding the Establishment of a Team for Audiovisual Policy and Digitization in the Field of Culture at the Ministry of Culture and National Heritage], http://bip.mkidn.gov.pl/pages/dzienniki-urzedowe-mkidn/dziennik-urzedowy-2010.php [accessed: 20.04.2020].

40 M. Dzięglewski, A. Guzik, M. Juza, Digitalizacja dziedzictwa kulturowego w Polsce - repozytoria cyfrowe jako potencjalne źródło dostępu do zasobów kulturowych [Digitization of Cultural Heritage in Poland - Digital Repositories as Potential Access Points to Cultural Resources], "Studia Humanistyczne AGH" 2017, Vol. 16(2), p. 92.

41 Narodowe Archiwum Cyfrowe, Szukajwarchiwach.gov.pl, https://www.nac.gov.pl/archiwum-cyfrowe/ systemy-i-infrastruktura-it/szukajwarchiwach-pl/ [accessed: 14.08.2020].

42 Ministerstwo Kultury i Dziedzictwa Narodowego, Program digitalizacji dóbr kultury oraz gromadzenia, przechowywania i udostępniania obiektów cyfrowych w Polsce 2009-2020, September 2009, http://www.digit.mkidn.gov.pl/media/dokumenty/dok_kultura_/Program_digitalizacji_dobr_kultury_oraz_gromadzenia_przechowywania_i_udostepniania_obiektow_cyfrowych_w_Polsce_2.pdf [accessed: 20.06.2020]. 43 Ibidem. 
Over the years, some legal changes have been made to the existing legislative instruments. These include the adaptation to modern digital technologies of the Act on Compulsory Library Copies; regulations in the sphere of orphan works; and the introduction of legal mechanisms regarding the provision of digital resources to which property rights belong to economic entities. At the same time, institutional instruments include, first and foremost, the establishment of Competence Centres, which aim to monitor and coordinate the digitization of cultural resources. Financial instruments are also very important, because digitization is a very costly undertaking and exceeds the financial capabilities of cultural institutions. Therefore, it was declared that digital repositories can be financed from either or both: the institution's own budget; the "Cultural Heritage" programme of the MCNH; as well as EU funds and EEA and Norway grants. The institutions coordinating digitization activities set out the priorities that should be implemented in the digitization work, while maintaining their public policies of respect for copyright and related rights as well as the protection of personal data. These priorities include, inter alia, the utility and frequent use of the object, its poor condition, value and uniqueness, as well as the special importance of given resources for national or regional culture. It is projected that by the end of 2020 at least 15 million objects will be digitized and placed in archives, libraries, virtual museums, and digital repositories. ${ }^{44}$ The first projects in the field of digitization were carried out thanks to European funds obtained under funding for the years 2004-2006 and for 2007-2013, as well as under the Financing Mechanism of the European Economic Area for 2009-2014 and the Norwegian Financing Mechanism for 2009-2014. By 2010 the Minister of Culture and Natural Heritage had already commissioned the creation of professional digital repositories, making collections available via the Internet and increasing the availability of collections of Polish museums, libraries, or archives of audiovisual collections and monuments. ${ }^{45}$ As part of the Norwegian grant, the main goal of the Programme of the Protection of Cultural Heritage was to protect, preserve, and share cultural heritage for future generations, including by digitizing collections. In total, 18 projects supported by the Norwegian Financing Mechanism have been able to undertake digitization processes, including the collections of the Juliusz Słowacki Theatre

\footnotetext{
44 Ibidem, p. 38.

45 Decyzja nr 12 Ministra Kultury i Dziedzictwa Narodowego z dnia 24 kwietnia 2006 r. w sprawie powołania Zespołu do spraw digitalizacji [Decision No. 12 of the Minister of Culture and National Heritage of 24 April 2006 on the Establishment of a Team for Digitization], http://bip.mkidn.gov.pl/pages/dzienniki-urzedowe-mkidn/dziennik-urzedowy-2006.php [accessed: 20.04.2020] and Decyzja $\mathrm{nr} 8$ Ministra Kultury i Dziedzictwa Narodowego z dnia 18 maja 2009 r. w sprawie powołania Zespołu do spraw digitalizacji [Decision No. 8 of the Minister of Culture and National Heritage of 18 May 2009 on the Establishment of a Team for Digitization], http://bip.mkidn.gov.pl/pages/dzienniki-urzedowe-mkidn/dziennik-urzedowy-2009.php [accessed: 20.04.2020].
} 


\section{DEBUTS}

Aleksandra Guss

in Kraków, the Royal Łazienki Museum in Warsaw, and the Library of the National Ossoliński Institute in Wrocław. ${ }^{46}$

Pursuant to Resolution No. 176/2010 of the Council of Ministers of 12 October 2010, ${ }^{47}$ the Multiannual Programme CULTURE+ (2011-2015) was established as a multi-year government programme aimed at improving public access to cultural heritage resources. It consists of two Priorities: "Library+. Library Infrastructure" and "Digitization". ${ }^{48}$ The purpose of the first one is further development of the housing base and equipment of municipal public libraries, while the goal of the "Digitization" priority is to support the digitization of cultural resources through the purchase of digitization equipment, support for the process itself, and the digital dissemination of digitized collections. ${ }^{49}$ In the context of this article, the second priority mentioned above is of significant importance. The intended goal was to carry out mass digitization of Polish cultural heritage objects and to develop the infrastructure for digitization. The responsibility for the implementation of digitization programmes falls on those cultural institutions selected by the Ministry, called Competence Centres: National Library (library resources), National Institute for Museum and Public Collections (museum resources), National Digital Archives (archive resources), National Film Archive - National Audiovisual Institute (audiovisual resources) and the National Heritage Institute (NID; monument resources). ${ }^{50}$ These Competence Centres implement technological changes related to the digitization and storage of digital data, coordinate their collection and storage, educate the staff of cultural institutions involved in digitization, and provide access to and promote digital resources. To a large extent, this allows for the appropriate coordination of digitization activities, depending on the subject the process concerns. The digitization process is characterized by a different equipment and specific actions and measures which have to be taken. For example, the digitization of monuments is different from the digitization of library resources. Therefore, the division of tasks into different centres is designed to provide for greater efficiency and accuracy in the digitization process.

46 S. Bienias et al., Ocena efektów oraz systemu zarządzania i wdrażania Mechanizmu Finansowego EOG 2009-2014 i Norweskiego Mechanizmu Finansowego 2009-2014. Raport końcowy [Assessment of the Results and the Management and Implementation System of the EEA Financial Mechanism 2009-2014 and the Norwegian Financial Mechanism 2009-2014. Final Report], p. 72, https://www.eog.gov.pl/media/69439/ Raport_koncowy_ewaluacja_MFEOG_NMF_20092014_PL.pdf [accessed: 21.06.2020].

47 Uchwała nr 176/2010 Rady Ministrów z dnia 12 października 2010 r. w sprawie ustanowienia programu wieloletniego "KULTURA+" [Resolution No. 176/2010 of 12 October 2010 of the Council of Ministers on Establishing a Multiannual Programme "CULTURE+"], http://bip.mkidn.gov.pl/media/download_gallery/20131009Uchwala_Nr_176-2010.pdf [accessed: 21.06.2020].

48 Ministerstwo Kultury i Dziedzictwa Narodowego, Program wieloletni KULTURA+ [Multiannual Programme CULTURE+], p. 8, http://www.digit.mkidn.gov.pl/media/dokumenty/dok_kultura_/PW_Kultura. pdf [accessed: 21.06.2020].

49 Ibidem, p. 10.

50 Ibidem. 
The main (central) institution that coordinates the Centres' activities is the $\mathrm{MCNH}$, which develops strategies and establishes the most important goals and priorities in the field of digitization and the sharing of digital resources. As part of the implementation of this part of the programme, well-equipped digitization workshops were to be created, primarily in the Competence Centres, as well as professional digital repositories. The main source of funding for the project was the state budget, in part allocated to the $\mathrm{MCNH}$, for which state and local cultural institutions, state archives, and film institutions could apply.

As part of the "Digitization" priority, a competition for digitization projects for local and state cultural institutions and state archives began in 2011. It provided beneficiaries with funds for the purchase of digitization equipment and the construction of digitization infrastructures, and not only were new laboratories created, but older ones were also modernized. Thus the implementation of the programme led to the creation of a network of digitization laboratories throughout Poland. ${ }^{51}$ Until 2015, it was possible within the Multiannual Programme CULTURE+ to create the MSN Artistic Film Library, which is a collection of audiovisual materials of unique artistic value; organize a 3D digitization workshop as well as a professional digital repository implemented by the Museum of King Jan III's Palace in Wilanów; organize a modern digitization workshop that digitized library originals from the public library collections of the Masovian Voivodeship; and digitize the "Ilustrowany Kuryer Codzienny". The programme has created an organized structure of entities involved in digitization, and now public cultural institutions (museums, archives, libraries), local government units, and non-governmental organizations can participate in competition procedures and carry out specific digitization projects.

The NID (acronym for Narodowy Instytut Dziedzictwa, in English the National Heritage Board) also undertook its own digitization activities, which have resulted in creation of the website zabytek.pl, which is currently a modern way to provide information about Polish monuments along with their descriptions, accompanying photos, attractive digital resources (e.g. 3D models of objects, point clouds, panoramas) and the location of objects. ${ }^{52}$

Moreover, in 2019 the NID started a new programme, entitled: "Digitization and sharing of digital cultural goods - monuments, graves, and war cemeteries", 53

\footnotetext{
51 Ministerstwo Kultury i Dziedzictwa Narodowego, Program wieloletni KULTURA+ [Multiannual Programme CULTURE+], http://www.digit.mkidn.gov.pl/pages/finansowanie/programy/program-wieloletni-kultura.php [accessed: 21.06.2020].

52 National Heritage Board of Poland, About the Project, https://zabytek.pl/en/o-projekcie?langset=true [accessed: 14.08.2020].

53 Narodowy Instytut Dziedzictwa, Digitalizacja i udostępnienie cyfrowych dóbr kultury - zabytków oraz grobów i cmentarzy wojennych, https://nid.pl/pl/Informacje_ogolne/Digitalizacja_zabytkow/DIGITALIZACJA I UDOSTĘPNIENIE CYFROWYCH DÓBR KULTURY - ZABYTKÓW ORAZ GROBÓW I CMENTARZY WOJENNYCH/ [accessed: 14.08.2020].
} 


\section{DEBUTS}

Aleksandra Guss

which is co-financed by the European Regional Development Fund under the Operational Programme Digital Poland. The aim of this project is to digitally reproduce the analogue resources at the disposal of the NID regarding all objects entered in the National Monuments Register (immovable monuments and archaeological sites), as well as record cards of war graves and cemeteries collected by Voivodeship Offices, and then make them publicly available via the Internet.

Apart from this institutional structure, there is also the wide array of activities of informal groups, individuals, and private institutions, which creates a grassroots digitization movement and which is increasingly becoming recognized by government agencies. ${ }^{54}$ One of the effects of activities undertaken by grassroots digitization movement is also the formulation - for the institutions involved in the digitization process - of Catalogues of Digitization Practices and Standards (currently they are properly formulated for library facilities, museum facilities, audiovisual materials, and archival materials). These catalogues constitute a set of requirements for the digitization of given resources, in particular the activities required in the digitization process as well as technical and quality standards.

Currently, and since 2016, the MCNH has been granting annual funding under the Digital Culture programme. The aim of the programme is to make available and enable the re-use of digital resources for popularization, educational, and scientific purposes, including the development and digitization of cultural heritage resources ${ }^{55}$ Local government cultural institutions, non-governmental organizations, as well as churches and religious associations and their legal representatives, may apply for funding under the programme. In addition, activities in the area of the digitization of cultural resources were implemented under the new EU funding perspective 2014-2020 (Operational Programme Digital Poland). As part of this programme, among others the project Patrimonium and the digitization and sharing of the Polish national heritage from the collections of the National Library and the Jagiellonian Library were implemented in 2018, and thanks to the project all the library heritage will be widely available to every internet user because they belong to the public domain, allowing for unlimited use in scientific, educational, artistic, and commercial purposes. ${ }^{56}$

As can be seen, the process of digitizing the resources of Polish cultural heritage involves both government administrative bodies (primarily the $\mathrm{MCNH}$ ), as well as non-governmental organizations and cultural institutions. This process requires

54 M. Dzięglewski, A. Guzik, M. Juza, op. cit., p. 95.

55 Ministerstwo Kultury i Dziedzictwa Narodowego, Kultura cyfrowa [Digital Culture], https://www.gov. $\mathrm{pl} /$ web/kultura/kultura-cyfrowa2 [accessed: 21.06.2020].

56 Biblioteka Narodowa, O projekcie [About the Project], https://www.bn.org.pl/projekty/patrimonium/ patrimonium---digitalizacja-i-udostepnienie-polskiego-dziedzictwa-narodowego-ze-zbiorow-biblioteki-narodowej/o-projekcie/ [accessed: 21.06.2020]. 
massive coordination in terms of its activities, as well as considerable financial outlays, both from the state budget and EU funds as well as from other sources of funding. Although undoubtedly the transfer of cultural goods to digital space is constantly progressing, expanding and including new objects, nevertheless there are still massive amounts of goods that have not been included in this process. This is due to, among other things, restrictions that arise from copyright.

\section{Digitization and Restrictions Resulting from the Act of 4 February 1994 on Copyright and Related Rights}

The digitization process may face copyright restrictions, which can make it difficult, if not impossible in some cases, to easily share and distribute all works on the Internet. This depends primarily on whether the objects being digitized are subject to someone's copyright, or whether they have already entered the public domain or are orphaned works.

The objective and subjective scope of application of copyright protection is determined by the Act of 4 February 1994 on Copyright and Related Rights (the Act). ${ }^{57}$ In determining whether a given cultural heritage object is subject to copyright, it is first necessary to refer to the statutory definition of the work. In accordance with Article 1(1) of the Act, a work is any manifestation of an individual's own creation, which is established, i.e. externalized, and communicated to third parties in any form. ${ }^{58}$ First of all, one should consider whether digitization leads to the creation of a subject of copyright. It seems that the doctrine has already developed a prevailing position in this respect, according to which it should be recognized that the digital mapping of a cultural heritage object, for example in the form of a photograph or scan, does not constitute a separate work and therefore no new copyright is created. ${ }^{59}$ Activities related to digitization, which are to a large extent the use of technology and knowledge in the field of its application, are not a manifestation of human creative activity, but only reproductive activities that have the character of documentary work. The purpose of digitization is to create the most accurate representation of a given object, i.e. its multiplication and an increase in its accessibility, which is simply a separate field of exploitation of the work..$^{60}$ This view is also espoused in the case law. The Polish

\footnotetext{
57 Ustawa z dnia 4 lutego 1994 r. o prawie autorskim i prawach pokrewnych, consolidated version: Dz.U. 2020 item 288.

58 J. Barta, R. Markiewicz, Prawo autorskie i prawa pokrewne [Copyright and Related Rights Law], Wolters Kluwer, Warszawa 2019, p. 22.

59 D. Urban, Prawne aspekty udostępniania obiektów muzealnych przez Internet [Legal Aspects of Making Museum Collections Available on the Internet], "Muzealnictwo" 2014, Vol. 55, p. 215.

60 W. Machała, R.M. Sarbiński (eds.), Prawo autorskie i prawa pokrewne. Komentarz [Copyright and Related Rights Law. A Commentary], LEX, 2019.
} 


\section{DEBUTS}

Aleksandra Guss

Supreme Court, in its judgment of 26 June 1998 (I PKN 196/98) clearly indicated that the activities of a photographer (renovator) do not include creative, but reproductive elements, because it was his/her duty not to take pictures of objects of art in a way that reflects an impressionist artistic endeavour by the photographer or express his/her artistic vision, but to take photos which reproduce - with the help of a medium, which is photography - the actual state of museum collections, hence to perform documentary activities. ${ }^{61}$ Often the issue of ownership of a given object (which is part of the resources of, for example, a museum or library) is mistakenly equated with the issue of ownership of the copyright to it. The fact that an institution has ownership of an object is not tantamount to having the copyright to it at the same time. It often happens that a given work is transferred to a cultural institution under a civil law agreement, in which there are so-called "soft clauses", according to which the author declares that he or she has full rights to the work. Therefore, determining the legal status of a given object - i.e. whether the object is a work within the meaning of copyright law or belongs to the public domain - is crucial in this process.

It seems that museum collections are a good example of cases where the digitization process meets up with copyright protection. ${ }^{62}$ The basic problem with digitizing museum resources is the diversity of objects stored in museums - their resources include paintings, sculptures, graphics, photographs, and architectural works (and naturalia, but they are excluded from copyright protection so they will not be taken into account here). It is extremely difficult to develop models that can be automatically applied to entire collections or all types of objects. Most often, each of the digitized objects requires a different approach. This feature fundamentally distinguishes the problems associated with the digital documentation of museum exhibits from the problems of digitization of the resources of libraries, archives, or audiovisual collections, for which it is possible to develop certain automated procedures. This difficulty also results from the variety of tasks that must be fulfilled by museum documentation. In accordance with the basic statutory provision, the duty of each museum is primarily to protect the objects entrusted to it. This includes, inter alia, preparing the best possible documentation of their state of preservation, conducting substantive and technological research to expand the knowledge concerning individual exhibits, and enabling their proper management (e.g. taking into account conservation restrictions when exhibiting).

As regards the issue of copyright protection, two distinct situations can occur - a given object may be a protected work within the meaning of copyright law,

\footnotetext{
61 Supreme Court (Poland), Judgment of 16 June 1998, I PKN 196/98, LEX No. 36707.

62 See Narodowy Instytut Muzealnictwa i Ochrony Zbiorów, Zalecenia dotyczące planowania i realizacji projektów digitalizacyjnych w muzealnictwie [Recommendations for Planning and Implementing Digitization Projects in Museums], Warszawa 2011, https://www.nimoz.pl/files/publications/54/Zalecenia_planowanie_i_realizacja_projektow_digitalizacyjnych_NIMOZ_2011.pdf [accessed: 18.08.2020].
} 
or the period of its protection may have expired and it has entered the public domain. ${ }^{63}$ If it is shown that the museum object belongs to the public domain, it can be freely transferred to digital space, distributed, and used. It is important to note that the licensing of such objects should be avoided, as this means imposing copyright restrictions on content that is not subject to copyright. Here one should recall the previously-presented position of the European Commission - the digitization process should not create any new rights and the elements that have entered the public domain should remain in it.

However, when an object meets the statutory conditions of a protected work, its legal documentation should be carefully analysed, i.e. whether the provisions of the contract with the author include provisions regarding the possibility of sharing the work on the Internet; for example whether the copyrights have been transferred in the field of specific exploitation fields, or whether licensing agreements have been concluded allowing the use of the work, with a clear indication that the fields of exploitation include making the work available on the Internet, and thus its digital reproduction, distribution, and introduction to the indicated databases. ${ }^{64}$ If it turns out that the museum has no regulated copyright to the object, then in order to be able to digitize it and make it available to a wider audience it is necessary to take actions to obtain such rights. This is often a complicated process, since it involves the determination of the author, and in the event of his or her death, of the legal heirs, and establishing contact with him/her or them. This is especially important because making the work available without the consent of its copyright owner carries the risk of incurring civil and criminal liability, which is why it has been assumed that in the event of any doubt as to the legal status of a given object, it should be interpreted in favour of copyright protection and then the necessary steps should be taken to clarify the uncertainty. In the event that digitization of a given object requires the consent of the copyright owner, the proper legal solution may take the form of either a contract for the transfer of author's economic rights, or a contract for periodic and/or specific uses of the work (i.e. a license).

Another interesting issue is the digitization of monuments, because immovable, movable, and archaeological monuments have a different specificity with respect to their digitization. Digital mapping of monuments must be accompanied by a rich set of metadata, and in the case of immovable monuments - their location data. Published information about monuments should be accompanied by their digital images (representing them as faithfully as possible). Monuments are most

\footnotetext{
63 Narodowy Instytut Muzealnictwa i Ochrony Zbiorów, Prawne aspekty digitalizacji i udostępniania zbiorów muzealnych przez Internet [Legal Aspects of Digitizing and Making Museum Collections Accessible via the Internet], Warszawa 2014, p. 8, https://nimoz.pl/files/publications/47/Prawne_aspekty_digitalizacji_i_ udostepniania_NIMOZ_2014.pdf [accessed: 14.09.2020].

64 Ibidem.
} 


\section{DEBUTS}

Aleksandra Guss

often viewed through the prism of their old age or antiquity, which is why it seems logical on the surface that copyright issues will not be applicable to them. In fact nothing could be more wrong - objects that do not have a long "lineage" can also be considered as monuments, such as the Palace of Culture and Science in Warsaw. So it is necessary to take into account the date of expiry of the author's economic rights and the requirements resulting from the protection of moral rights that have not expired. As regards the digitization process itself, the NID, which is responsible for the digitization of monuments, had to first of all determine the criteria for selecting monuments for digitization, identify the priority groups (historical monuments, monuments that are on the UNESCO World Heritage List, and immovable and archaeological monuments entered in the register), and digitize all administrative decisions regarding the entry of a monument onto the register of monuments. In addition, another important activity was the construction of appropriate technical infrastructure (such as 3D scanners), and the organization of appropriate digitization laboratories and professional digital repositories. Monuments are disseminated by sharing their information (geolocation data, photos, descriptions, and 3D models) on public portals (e.g. the NID map-portal ${ }^{65}$ or website zabytek.pl, ${ }^{66}$ as well as Europeana) and in mobile applications.

Copyright law, however, provides exceptions to the requirement to obtain the author's consent to use the work in the form of "permitted use" as part of creating a digital copy of the object. Copyright provisions weaken the protection of personal rights due to the existence of higher values, including public access to information (here cultural goods), which have their legitimate place in the Polish Constitution and/or statutory EU regulations. ${ }^{67}$ As part of permitted use, the law allows, inter alia, legal and free use of works protected by copyright under strictly defined situations, including by scientific and educational institutions. ${ }^{68}$ Permitted uses can be personal or institutional - the latter applies to educational institutions, universities, research institutes, scientific institutes of the Polish Academy of Sciences, museums, and archives. It entitles them to three forms of exploitation of works: 1) lending copies of widespread works within the scope of statutory tasks; 2) reproduction of works in their own collections in order to supplement, preserve, or protect them; and 3) making the collections available for research or cognitive purposes via the system ends IT (so-called terminals). The condition for invoking this statutory license is that these activities are not carried out in order to achieve a direct or indirect financial advantage, although fees may be charged so long as they do not exceed "the amount necessary to cover the costs of servicing the institu-

\footnotetext{
65 https://mapy.zabytek.gov.pl/nid/ [accessed: 21.08.2020].

66 https://zabytek.pl/pl [accessed: 21.08.2020].

67 J. Barta, R. Markiewicz, op. cit., p. 150.

68 Ibidem.
} 
tion". ${ }^{69}$ The scope of digitization within such permitted uses is problematic, because the question arises how to delineate between necessary digitization for the use of works for research, and private studies - after all, every object may be needed for such activities, but at the same time its digitization and subsequent access is not necessarily required.

What is also worth mentioning is the issue of metadata shared with the digitized object in the context of copyright. Metadata consists of information used, for example, to describe objects. Metadata provide detailed data on the features of objects in order to facilitate their identification and management. They provide information about data such as the title, author, and keywords that describe the information resource or object. The standard for sharing copyrighted metadata in Europe was defined in 2012 as part of the process of aggregating data from European cultural institutions on the Europeana website. All resource metadata on sites which are subject to copyright are made available using the Creative Commons Zero (CCO) license mechanism. This mechanism is designed to enable the sharing of copyrighted works on an equal footing with works in the public domain. The Polish copyright system does not allow for full use of the CCO provisions, as it assumes the non-transferability of moral rights and the inability to waive these rights. CCO does, however, contain an additional licensing mechanism with effects similar to a waiver of moral rights. It consists of granting a broad license that allows any use of the work, even without the requirement to provide authorship. At the same time, it is assumed that making the work available via the CCO mechanism is tantamount to a commitment not to exercise an author's moral rights. Thus, metadata made available through the $\mathrm{CCO}$ mechanism can be used without any restrictions.

Another problem is the acceptability of the digitization of collections (including those covered by copyright) when this is not done for the purpose of access, but only for the protection and preservation of objects for subsequent generations. Here, in accordance with the law of lege non distinguente nec nostrum est distinguere, it seems that the provisions in Article 28(1) point 2 of the copyright law ${ }^{70}$

69 Ibidem, p. 189.

70 "Article 28(1) Educational institutions, universities, leading research institutes the activity referred to in art. 2 clause 3 of the Act of April 30, 2010 on research institutes (Journal of Laws of 2018, item 736 and 1669 and of 2019, item 534), scientific institutes of the Polish Academy of Sciences conducting activities referred to in Art. 50 sec. 4 of the Act of 30 April 2010 on the Polish Academy of Sciences (Journal of Laws of 2018, items 1475 and 1669 and of 2019, item 534), libraries, museums and archives may:

1) lend, within the scope of its statutory tasks, copies of disseminated works,

2) reproduce works from their own collections in order to supplement, preserve or protect these collections,

3) make collections available for research or cognitive purposes via the terminals of the IT system (terminals) located on the premises of these units - if these activities are not performed in order to achieve direct or indirect material benefit.

(2) The reproduction referred to in paragraph 1.1, point 2, may not lead to an increase in the number of copies of works and an increase in collections, respectively lent and made available on the basis of paragraph 1 points 1 and 3 . 


\section{DEBUTS}

Aleksandra Guss

do not stand in the way of digitization of the entire collection (even those objects which are copyrighted) ${ }^{71}$ This is a quite controversial thesis, because there is no requirement that the multiplied works have to be distributed works. In this case, there was a specific intent behind this provisions. The draft of the Act specifies that such a requirement grant, for example, libraries the possibility of digitizing (in order to protect their own collections) works that were not previously made available to the public with the consent of the creator, e.g. manuscripts found only after the creator's death. ${ }^{72}$ This approach is also supported by the content of Commission Recommendation of 24 August 2006 on the digitization and online accessibility of cultural material and digital preservation, which in Point 9 explicitly indicates that Member States should "make provision in their legislation so as to allow multiple copying and migration of digital cultural material by public institutions for preservation purposes, in full respect of Community and international legislation on intellectual property rights". So if the goal of digitization is itself to protect and preserve cultural heritage, all collections can be transferred to digital space. However, it should be considered whether - regardless of the intention of the designer the necessity to meet the requirement of prior dissemination of the work does not result from the obligation to respect the author's personal right to decide on the first release to the public. ${ }^{73}$ What is still worth mentioning, and of particular importance in the case of cultural heritage, is the issue of the digitization and subsequent sharing of so-called "orphan works", i.e. works for which the issue of the author's economic rights cannot be determined. The Polish legal solutions transpose Directive 2012/28/EU on certain permitted uses of orphan works. The exploitation of such works is - in accordance with Article $35^{5}(2)$ of the copyright law - limited to reproduction and public sharing in such a way that everyone can have access to them at the place and time chosen by them. A condition for using such a work is that a careful search for the entities with potential copyright(s) to the work has been carried out and no such entities were found.

Finally, it is necessary to underline the problem of achieving the goal of digitizing a collection while maintaining the aims underlying copyright protection. Cultural heritage is often perceived as a common good, ${ }^{74}$ and the original idea

(3) The provision of paragraph 1 point 3 shall not apply if the disclosure in the manner specified therein takes place on the basis of a previously concluded contract with an authorized entity".

71 J. Barta, R. Markiewicz, op. cit., p. 191.

72 B. Błońska, Art. 28, in: W. Machała, R.M. Sarbiński (eds.), Prawo autorskie i prawa pokrewne. Komentarz, LEX, 2019.

73 Ibidem.

74 See K. Zalasińska, Interes indywidualny a interes publicznych - konflikt wartości w prawnej ochronie zabytków [Individual interests and the Public Interest - A Conflict of Values in the Legal Protection of Historical Monuments], "Ochrona Zabytków" 2008, Vol. 2, pp. 83-85; J.H. Merryman, The Public Interest in Cultural Property, "California Law Review" 1989, Vol. 77(2), p. 339; K. Zeidler, Restytucja dóbr kultury ze stanowiska filozofii prawa. O trudnych przypadkach na granicy kultury i prawa [Restitution of Cultural Property from 
of copyright was to protect the interests of creators while ensuring access to their works in the name of the public interest. ${ }^{75}$ Currently, the proprietary concept of copyright has been adopted based on a kind of compromise - the creator has a monopoly for a specific period of time to dispose of his/her work, and after this period his/her rights expire and pass into the public domain, becoming the property of the general public. This partly closes the way for society to get to know their cultural heritage. As mentioned earlier, the Polish Constitution, in Article 6(1), indicates that Poland creates conditions for the dissemination and equal access to those cultural goods which area source of identity of the Polish nation, as well as secures their duration and development. This is also confirmed by Article 73, according to which everyone is guaranteed the freedom to use cultural goods. Moreover, many people treat copyright protections as a restriction of the right to access to public information (based on Article 61 of the Constitution) and the right to re-use public information, which is a type of economic law. ${ }^{76}$ In most cases, the resources of public cultural institutions are produced and stored using public money, and these institutions carry out a public mission in the form of organizing and providing access to the achievements of science and culture, while serving the national economy and the needs of citizens, shaping their cognitive and aesthetic values, and conducting business in an educational manner. ${ }^{77}$ However, both Directive 2003/98/EC of the European Parliament and of the Council of 17 November 2003 on the re-use of public sector information, ${ }^{78}$ as well as the Polish Act of 25 February 2016 on the Re-use of Public Sector Information ${ }^{79}$ which implements it, are limited by the existence of intellectual property rights which may place limits on the sharing of objects in the public domain, or intellectual property rights, both primary and derivative, of which the cultural institution is the owner.

It seems that in order to achieve the goal of digitization, it is important to introduce a resource openness model. The resource openness model assumes a significant change in the way of thinking about the mission and functioning of modern

the Standpoint of Legal Philosophy. Hard Cases Across Culture and Law], Warszawa 2011, pp. 99-100; M. Sanderhoff, Foreword, in: Sharing is Caring. Openness and Sharing in the Cultural Heritage Sector, Statens Museum for Kunst, Copenhagen 2014, p. 9.

75 P.A. González, Conceptualizing Cultural Heritage as a Common, in: P.F. Biehl et al. (eds.), Identity and Heritage: Contemporary Challenges in a Globalized World, Springer Publishing, Cham 2014, pp. 27-35.

76 K. Rybicka, H. Rymar, A. Tarkowski, Ponowne wykorzystywanie informacji publicznej. Nowe wyzwanie dla instytucji kultury [Re-use of Public Information. A New Challenge for Cultural Institutions], Centrum Cyfrowe, Warszawa 2015, p. 10.

77 Ibidem, p. 12.

78 OJ L 345, 31.12.2003, p. 90.

79 Ustawa z dnia 25 lutego 2016 r. o ponownym wykorzystywaniu informacji sektora publicznego, Dz.U. 2016 item 352. 


\section{DEBUTS}

Aleksandra Guss

cultural and heritage institutions, in which the issue of the availability and the possibility of further use of resources under their care plays a significant role. ${ }^{80}$ This can also be treated more broadly - as an innovative concept of using digital technologies to implement the institutions' missions. ${ }^{81}$ An indispensable condition for its implementation is therefore raising the competences of staff, including media and communication competences, knowledge of copyright, and understanding how to use content in a digital environment and in the changing context of cultural institutions. The use of Creative Commons licenses, which is usually seen as the first step towards openness, entails further changes in the organizations' operations and requires employees to acquire new competences. When using the license, the creator always retains the copyrights, while at the same time allowing others to copy and distribute. Additionally, he/she may specify whether their use may take place only in non-commercial conditions and/or limit the possibility of creating derivative works. This is based, as mentioned earlier, on the copyright transfer agreement and covers only the forms and fields of exploitation expressly mentioned therein. An author choosing a Creative Commons license needs to answer two simple questions in order to choose the correct license terms. First: does he/she want to allow commercial use of his or her works? Second, does he/she consent to the creation of derivative works from the original, and if so, does he/she also wish to require that such derivative works be available under the same license? In contrast to the traditional model of copyright, which is expressed by the maxim "all rights reserved", the Creative Commons license makes it easy to share your creativity by following the principle of "certain rights reserved". It seems that a properly composed model of resource openness could be a good buffer between the digitization of cultural heritage goods and the existence of copyrights to some of these resources, without damage to either party. Despite this, cultural institutions remain sceptical about the policy of openness and the resource openness model remains a slowly implemented idea.

Undoubtedly for the aforementioned reasons the digitization policy in Poland is not yet fully developed, and in the future some compromises should be made on both sides so that on the one hand society can enjoy a culture that is an integral part of its identity, while on the other hand the creators who own the copyright to given works can count on being protected and reaping the possible benefits due them.

80 A. Buchner et al., Otwartość w instytucjach kultury. Raport z badań [Openness in Cultural Institutions. Research Report], Centrum Cyfrowe, Warszawa 2015, p. 13.

81 Ibidem. 


\section{Conclusions}

The digitization of cultural resources and their sharing on the Internet has already become a common practice, used by both public cultural institutions and private organizations with interesting collections or access to such collections. The transfer of cultural goods to digital space is primarily aimed at their protection and the consolidation of heritage for future generations, thus making it available to the public so that they can derive knowledge from them. EU regulations are the foundation on which the frameworks for the digitization mechanisms of European countries, including Poland, are based. EU policy aims to create a digital single market and ensure that the widest possible digital catalogue of cultural goods will be open to the public.

For over ten years now Poland has been intensively implementing the EU vision focused on digitizing the resources of its cultural heritage. The first steps were taken by the libraries, archives, museums, non-governmental organizations, and other entities, under so-called "grassroots digitization". Thanks to this, many archives of digitized resources have been created, as well as digital libraries and social digitization workshops. Then, as part of European funding programmes, which certainly made it possible to create a strong foundation for later digitization processes, since the year 2009 Polish national programmes - such as the Multiannual Programme CULTURE+ and annual "Digital Culture" projects - have been implemented with the strong involvement of the $\mathrm{MCNH}$.

It can be seen, however, that the main obstacle on the path to expanding the space of digitized resources of Polish culture is copyright law. In a situation where a given object is protected by copyright, or its status is unknown, the institution must take the necessary actions to obtain the author's appropriate consent to share and disseminate the work online. The activities of the institutions in which the digitization works are taking place are essential to maintaining an appropriate coordinated and orderly documentation, but their legal status needs to be regulated and clarified.

Thus it seems desirable for the Polish State to take a step towards regulating this issue in line with the policy of openness, which would be the result of a compromise; by which on the one hand would pursue one of the main objectives of digitization, i.e. the protection of cultural heritage and making it available to a wider audience, while and on the other hand would support the creators of copyrighted works.

\section{References}

Barta J., Markiewicz R., Prawo autorskie i prawa pokrewne [Copyright and Related Rights Law], Wolters Kluwer, Warszawa 2019.

Biblioteka Narodowa, O projekcie [About the Project], https://www.bn.org.pl/projekty/patrimonium/patrimonium---digitalizacja-i-udostepnienie-polskiego-dziedzictwa-narodowego-ze-zbiorow-biblioteki-narodowej/o-projekcie/ [accessed: 21.06.2020]. 


\section{DEBUTS}

Aleksandra Guss

Bienias S. et al., Ocena efektów oraz systemu zarządzania i wdrażania Mechanizmu Finansowego EOG 2009-2014 i Norweskiego Mechanizmu Finansowego 2009-2014. Raport końcowy [Assessment of the Results and the Management and Implementation System of the EEA Financial Mechanism 2009-2014 and the Norwegian Financial Mechanism 2009-2014. Final Report], https://www.eog.gov.pl/media/69439/Raport_koncowy_ ewaluacja_MFEOG_NMF_20092014_PL.pdf [accessed: 21.06.2020].

Bożek A., Kamińska-Mazur L., Europeana - cyfrowa kolekcja europejskiego dziedzictwa kultury [Europeana - A Digital Collection of European Cultural Heritage], "Folia Bibliologica" 2009, Vol. 51.

Brennen J.S., Kreiss D., Digitization, in: K. Jensen et al. (eds.), The International Encyclopedia of Communication Theory and Philosophy, Wiley-Blackwell, Chichester 2016.

Buchner A. et al., Otwartość w instytucjach kultury. Raport z badań [Openness in Cultural Institutions. Research Report], Centrum Cyfrowe, Warszawa 2015.

Charter on the Preservation of Digital Heritage, 15 October 2003, http://portal.unesco. org/en/ev.php-URL_ID=17721\&URL_DO=DO_TOPIC\&URL_SECTION=201.html [accessed: 18.06.2020].

Commission Recommendation of 24 August 2006 on the digitization and online accessibility of cultural material and digital preservation, OJ L 236, 31.08.2006, p. 28.

Commission Recommendation of 27 October 2011 on the digitization and online accessibility of cultural material and digital preservation, OJ L 283, 29.10.2011, p. 39.

Council of Europe, Cultural Heritage Policy in Poland - National Policy Report, https://www. coe.int/en/web/herein-system/poland [accessed: 21.06.2020].

Council Resolution of 25 June 2002 on preserving tomorrow's memory - preserving digital content for future generations, OJ C 162, 6.07.2002, p. 4.

de la Durantaye K., Finding a Home for Orphans: Google Book Search and Orphan Works Law in the United States and Europe, "Fordham Intellectual Property, Media \& Entertainment Law Journal" 2010, Vol. 21(2).

Decyzja nr 8 Ministra Kultury i Dziedzictwa Narodowego z dnia 18 maja 2009 r. w sprawie powołania Zespołu do spraw digitalizacji [Decision No. 8 of the Minister of Culture and National Heritage of 18 May 2009 on the Establishment of a Team for Digitization], http://bip.mkidn.gov.pl/pages/dzienniki-urzedowe-mkidn/dziennik-urzedowy-2009. php [accessed: 20.04.2020].

Decyzja nr 12 Ministra Kultury i Dziedzictwa Narodowego z dnia 24 kwietnia 2006 r. w sprawie powotania Zespołu do spraw digitalizacji [Decision No. 12 of the Minister of Culture and National Heritage of 24 April 2006 on the Establishment of a Team for Digitization], http://bip.mkidn.gov.pl/pages/dzienniki-urzedowe-mkidn/dziennik-urzedowy-2006. php [accessed: 20.04.2020].

Directive (EU) 2019/790 of the European Parliament and of the Council of 17 April 2019 on copyright and related rights in the Digital Single Market and amending Directives 96/9/EC and 2001/29/EC, OJ L 130, 17.05.2019, p. 92.

Directive 2001/29/EC of the European Parliament and of the Council of 22 May 2001 on the harmonisation of certain aspects of copyright and related rights in the information society, OJ L 167, 22.06.2001, p. 10.

Directive 2003/98/EC of the European Parliament and of the Council of 17 November 2003 on the re-use of public sector information, OJ L 345, 31.12.2003, p. 90. 
Directive 2012/28/EU of the European Parliament and of the Council of 25 October 2012 on certain permitted uses of orphan works (Text with EEA relevance), OJ L 299, 27.10.2012, p. 5.

Drela M., Culture Goods in the Public Domain under Polish Law - Acquiring and Disposing Difficulties, "Santander Art and Culture Law Review" 2015, Vol. 2.

Dzięglewski M., Guzik A., Juza M., Digitalizacja dziedzictwa kulturowego w Polsce - repozytoria cyfrowe jako potencjalne źródło dostępu do zasobów kulturowych [Digitization of Cultural Heritage in Poland - Digital Repositories as Potential Access Points to Cultural Resources], "Studia Humanistyczne AGH" 2017, Vol. 16(2).

Europeana, Public Domain Charter, https://www.europeana.eu/pl/rights/public-domain-charter [accessed: 17.04.2020].

González P.A., Conceptualizing Cultural Heritage as a Common, in: P.F. Biehl et al. (eds.), Identity and Heritage: Contemporary Challenges in a Globalized World, Springer Publishing, Cham 2014.

Jakubowski A., Hausler K., Fiorentini F., Final Conclusions, in: A. Jakubowski, K. Hausler, F. Fiorentini (eds.), Cultural Heritage in the European Union: A Critical Inquiry into Law and Policy, Brill, Boston-Leiden 2019.

Konstytucja Rzeczypospolitej Polskiej z dnia 2 kwietnia 1997 r. [Constitution of the Republic of Poland of 2 April 1997], Dz.U. 1997 No. 78 item 483.

Koszowska A., Lis R., Społeczna Pracownia Digitalizacji ŚBC [Social Digitization Workshop of the SDL], "Biblioteka 2.0", 30 September 2007, http://blog.biblioteka20.pl/?p=49 [accessed: 21.06.2020].

Machała W., Sarbiński R.M. (eds.), Prawo autorskie i prawa pokrewne. Komentarz [Copyright and Related Rights Law. Commentary], LEX, 2019.

Manikowska E., Digitization: Towards a European Cultural Heritage, in: A. Jakubowski, K. Hausler, F. Fiorentini (eds.), Cultural Heritage in the European Union: A Critical Inquiry into Law and Policy, Brill, Boston-Leiden 2019.

McCain R., Defining Cultural and Artistic Goods, in: V.A. Ginsburg, D. Throsby (eds.), Handbook of the Economics of Art and Culture, Vol. I, North-Holland, Amsterdam 2006.

Merryman J.H., The Public Interest in Cultural Property, "California Law Review" 1989, Vol. 77(2).

Ministerstwo Kultury i Dziedzictwa Narodowego, Kultura cyfrowa [Digital Culture], https:// www.gov.pl/web/kultura/kultura-cyfrowa2 [accessed: 21.06.2020].

Ministerstwo Kultury i Dziedzictwa Narodowego, O digitalizacji [On Digitization], http:// kulturacyfrowa.mkidn.gov.pl/pages/digitalizacja/o-digitalizacji.php [accessed: 14.08.2020].

Ministerstwo Kultury i Dziedzictwa Narodowego, Program digitalizacji dóbr kultury oraz gromadzenia, przechowywania i udostępniania obiektów cyfrowych w Polsce 2009-2020 [The Programme of Digitization of CulturalGoods and the Collection, Storage and Sharing of Digital Objects in Poland 2009-2020], September 2009, http://www.digit.mkidn.gov.pl/media/dokumenty/dok_kultura_/Program_digitalizacji_dobr_kultury_oraz_gromadzenia_przechowywania_i_udostepniania_obiektow_cyfrowych_w_ Polsce_2.pdf [accessed: 20.06.2020].

Ministerstwo Kultury i Dziedzictwa Narodowego, Program wieloletni KULTURA+ [Multiannual Programme CULTURE+], http://www.digit.mkidn.gov.pl/media/dokumenty/dok_ kultura_/PW_Kultura.pdf [accessed: 21.06.2020]. 


\section{DEBUTS}

Aleksandra Guss

Ministerstwo Kultury i Dziedzictwa Narodowego, Program wieloletni KULTURA+ [Multiannual Programme CULTURE+], http://www.digit.mkidn.gov.pl/pages/finansowanie/ programy/program-wieloletni-kultura.php [accessed: 21.06.2020].

Narodowe Archiwum Cyfrowe, Szukajwarchiwach.gov.pl, https://www.nac.gov.pl/ archiwum-cyfrowe/systemy-i-infrastruktura-it/szukajwarchiwach-pl/ [accessed: 14.08.2020].

Narodowy Instytut Dziedzictwa, Digitalizacja i udostępnienie cyfrowych dóbr kultury - zabytków oraz grobów i cmentarzy wojennych [Digitization and Sharing of Digital Cultural Goods - Monuments, Graves and War Cemeteries], https://nid.pl/pl/Informacje_ ogolne/Digitalizacja_zabytkow/DIGITALIZACJA I UDOSTĘPNIENIE CYFROWYCH DÓBR KULTURY - ZABYTKÓW ORAZ GROBÓW I CMENTARZY WOJENNYCH/ [accessed: 14.08.2020].

Narodowy Instytut Muzealnictwa i Ochrony Zbiorów, Prawne aspekty digitalizacji i udostępniania zbiorów muzealnych przez Internet [Legal Aspects of Digitizing and Making Museum Collections Accessible via the Internet], Warszawa 2014, https://nimoz.pl/files/ publications/47/Prawne_aspekty_digitalizacji_i_udostepniania_NIMOZ_2014.pdf [accessed: 14.09.2020].

Narodowy Instytut Muzealnictwa i Ochrony Zbiorów, Zalecenia dotyczące planowania i realizacji projektów digitalizacyjnych w muzealnictwie [Recommendations for Planning and Implementing Digitization Projects in Museums], Warszawa 2011, https://www. nimoz.pl/files/publications/54/Zalecenia_planowanie_i_realizacja_projektow_digitalizacyjnych_NIMOZ_2011.pdf [accessed: 18.08.2020].

National Heritage Board of Poland, About the Project, https://zabytek.pl/en/o-projekcie?langset=true [accessed: 14.08 .2020$]$.

Pietruch-Reizes D., Digitalizacja i rozpowszechnianie utworów osieroconych w świetle dyrektywy Parlamentu Europejskiego i Rady 2012/28/UE z 25 października 2012 r. [Digitization and Distribution of Orphan Works under Directive 2012/28/EU of the European Parliament and of the Council of 25 October 2012], "Przegląd Biblioteczny" 2014, Vol. 4.

Purday J., Europeana: Digital Access to Europe's Cultural Heritage, "Alexandria: The Journal of National and International Library and Information Issues" 2012, Vol. 23(2).

Ramalho A., The Competence of the European Union in Copyright Lawmaking. A Normative Perspective of EU Powers for Copyright Harmonization, Springer Publishing, Cham 2016.

Rybicka K., Rymar H., Tarkowski A., Ponowne wykorzystywanie informacji publicznej. Nowe wyzwanie dla instytucji kultury [Re-use of Public Information. A New Challenge for Cultural Institutions], Centrum Cyfrowe, Warszawa 2015.

Sanderhoff M., Foreword, in: Sharing is Caring. Openness and Sharing in the Cultural Heritage Sector, Statens Museum for Kunst, Copenhagen 2014.

Śląska Biblioteka Cyfrowa, Społeczna Pracownia Digitalizacji ŚBC [Social Digitization Workshop of the SDL], https://www.sbc.org.pl/dlibra/text?id=spd\&amp;language=pl [accessed: 21.06.2020].

Stainforth E., From Museum to Memory Institution: The Politics of European Culture Online, "Museum \& Society" 2016, Vol. 14(2).

Supreme Court (Poland), Judgment of 16 June 1998, I PKN 196/98, LEX No. 36707.

Suthersanen U., Property and Culture: A Case Study on Orphan Works, "Art Antiquity and Law" 2017, Vol. 22(2). 
Tarkowski A.,Hofmokl J., Wilkowski M., Digitalizacja oddolna. Partycypacyjny wymiar procesu digitalizacji dziedzictwa [Bottom-up Digitization. The Participatory Dimension of Heritage Digitization], http://www.nina.gov.pl/media/43941/digitalizacja-oddolna.pdf [accessed: 21.06.2020].

The U.S. National Archives and Records Administration, Strategy for Digitizing Archival Materials, https://www.archives.gov/digitization/strategy.html [accessed: 14.08.2020].

Treaty on the Functioning of the European Union (consolidated version), OJ C 202, 7.06.2016, p. 47.

Uchwała nr 82 Rady Ministrów z dnia 13 sierpnia 2019 r. w sprawie „Krajowego programu ochrony zabytków i opieki nad zabytkami na lata 2019-2022" [Resolution No. 82 of the Council of Ministers of 13 August 2019 regarding the "National Programme for the Protection of Monuments and Care for Monuments for the Years 2019-2022"], http://isap.sejm. gov.pl/isap.nsf/download.xsp/WMP20190000808/O/M20190808.pdf [accessed: 21.06.2020].

Uchwała nr 125/2014 Rady Ministrów z dnia 24 czerwca 2014 r. w sprawie „Krajowego programu ochrony zabytków i opieki nad zabytkami" [Resolution No. 125 of the Council of Ministers of 24 June 2014 regarding the "National Programme for the Protection of Monuments and Care for Monuments"], http://bip.mkidn.gov.pl/media/download_gallery/20140818Krajowy_Program_Ochrony_Zabytkow_i_Opieki_nad_Zaby.pdf [accessed: 21.06.2020].

Uchwała nr 176/2010 Rady Ministrów z dnia 12 października 2010 r. w sprawie ustanowienia programu wieloletniego "KULTURA+” [Resolution No. 176/2010 of 12 October 2010 of the Council of Ministers on Establishing a Multiannual Programme "CULTURE+"], http://bip.mkidn.gov.pl/media/download_gallery/20131009Uchwala_Nr_176-2010. pdf [accessed: 21.06.2020].

UNESCO, Fundamental Principles of Digitization of Documentary Heritage, http://www.unesco.org/new/fileadmin/MULTIMEDIA/HQ/Cl/Cl/pdf/mow/digitization_guidelines_ for_web.pdf [accessed: 14.08.2020].

Urban D., Prawne aspekty udostępniania obiektów muzealnych przez Internet [Legal Aspects of Making Museum Collections Available on the Internet], "Muzealnictwo" 2014, Vol. 55.

Ustawa z dnia 25 lutego 2016 r. o ponownym wykorzystywaniu informacji sektora publicznego [Act of 25 February 2016 on the Re-use of Public Sector Information], Dz.U. 2016 item 352.

Ustawa z dnia 4 lutego 1994 r. o prawie autorskim i prawach pokrewnych [Act of 4 February 1994 on Copyright and RelatedRights], consolidated version: Dz.U. 2020 item 288.

Valtysson B., Europeana. The Digital Construction of Europe's Collective Memory,"Information, Communication \& Society Journal” 2012, Vol. 15(2).

Wasiołka T., Ochrona dziedzictwa kulturowego na tle standardów europejskich [Protection of Cultural Heritage Compared to European Standards], unpublished MA thesis, University of Zielona Góra, Zielona Góra 2017.

Zalasińska K., Interes indywidualny a interes publicznych - konflikt wartości w prawnej ochronie zabytków [Individual and Public Interest - A Conflict of Values in the Legal Protection of Historical Monuments], "Ochrona Zabytków" 2008, Vol. 2.

Zarządzenie nr 23 Ministra Kultury i Dziedzictwa Narodowego z dnia 16 września 2010 r. w sprawie powołania Zespołu do spraw polityki audiowizualnej i cyfryzacji w dziedzinie kultury w Ministerstwie Kultury i Dziedzictwa Narodowego [Ordinance No. 23 of the Minister 


\section{DEBUTS}

Aleksandra Guss

of Culture and National Heritage of 16 September 2010 regarding the Establishment of a Team for Audiovisual Policy and Digitization in the Field of Culture at the Ministry of Culture and National Heritage], http://bip.mkidn.gov.pl/pages/dzienniki-urzedowe-mkidn/dziennik-urzedowy-2010.php [accessed: 20.04.2020].

Zeidler K., Prawo ochrony dziedzictwa kultury [Law on the Protection of Cultural Heritage], Wolters Kluwer, Warszawa 2007.

Zeidler K., Restytucja dóbr kultury ze stanowiska filozofii prawa. O trudnych przypadkach na granicy kultury i prawa [Restitution of Cultural Property from the Standpoint of Legal Philosophy. Hard Cases Across Culture and Law], Warszawa 2011.

Zeidler K., Zasady prawa ochrony dziedzictwa kultury - propozycja katalogu [The Principles of the Law on the Protection of Cultural Heritage - A Proposal for a Catalogue], "Ruch Prawniczy, Ekonomiczny i Socjologiczny" 2018, Vol. 4. 